\title{
Victims and survivors from Cyangugu, Rwanda: the politics of testimony after genocide
}

\section{Rachel Ibreck}

'When I went back, I discovered that my home was not there anymore. It was totally destroyed. I was the only Tutsi who had not died; there were hardly any left in the whole sector or commune. I felt isolated. I also felt afraid that I too would be killed.' Claude, a Tutsi from Cyangugu, Rwanda, $1994 .^{1}$

'I asked them why they had come to see me. They said: 'because we know you collaborate with the Tutsis. But this time you have to show your commitment and help to kill the Tutsis.' I told them: 'firstly, I am not prepared to kill anyone. Secondly there should be an investigation to establish the truth about what has happened. And then whoever is responsible, Tutsi or Hutu or someone else, should be punished by the law.' Félicien, a Hutu from Cyangugu, Rwanda, $1994 .^{2}$

Victim testimony is foundational to the pursuit of justice and social repair after mass atrocities and should be recognised as an expression of courage and transformative political agency. After the 1994 genocide in Rwanda, survivors recounted horrors that could hardly be communicated, creating precious records of human suffering and loss. Since then, other victims of injustice and abuse have also given testimony to human rights organisations, despite fears of repression. Taken on their own terms, these harrowing individual testimonies are profound critiques of atrocities and political violence. Collectively, they form a powerful legacy and a counterpoint to narrow political framings of Rwanda's history.

The massacre of close to a million people in Rwanda between 6 April and 17 July 1994 is officially remembered as the 'genocide against the Tutsi'. This accurately describes the intent of the genocide and the identities of most of the victims (Prunier, 1998; Des Forges, 1999). In the words of one survivor: 'People were executed every day throughout four months... because they were Tutsi' (Rurangwa, 2009, p.13-14). While scholars continue to debate questions of how and why, there is a consensus on the basic facts of the genocide: 'Hutu leaders planned the violence... and deliberately attempted to eliminate a racially defined minority' (Straus, 2006, p. 33). Still, the identification and categorization of victims has been complicated by fluid identities and intricate social relations at the micro-level, that produced 'ambiguity and contradiction' (Fujii, 2009, p. 8). Some Hutus were targeted during the genocide for their principles and actions, in interpersonal violence or criminality, or were inadvertently killed, and some were killed in the war; there were 'multiple vectors of violence occurring at the same time' (ibid, p. 81). Additionally, the defeat of the genocidal state did not equate to the end of political violence, as the post-genocide Rwandan Patriotic Front (RPF) regime stands accused of political violence, including human rights abuses, war crimes and crimes against humanity, either within Rwanda or in neighbouring Congo (Prunier, 2009, pp. 15-23; Reyntjens, 2015, pp. 2528).

After the genocide, the RPF government embarked upon an expansive state-led programme to promote the memory of the genocide and bring the perpetrators to justice. This endeavour duly recognised the scale and intensity of the atrocities and the importance of ending impunity and ensuring accountability for genocide crimes against Tutsis, including murder, torture, rape and looting. It also adopted and extended some of the early initiatives by survivors to create memorials for the victims (Ibreck, 2010, p. 334-5), and provided spaces and times to acknowledge their grief and trauma in the public sphere. But these official mechanisms for genocide prosecutions and commemorations side-lined or suppressed complex and plural experiences of the genocide and its aftermath (Burnet, 2009).

In many ways, the RPF has managed to harness the genocide to political objectives with 'deft authoritarianism' (Straus and Waldorf, 2011, p. 4) while repressing both Hutu and Tutsi opponents or critics. ${ }^{3}$ State-led processes have focused upon a 'collective Tutsi victimization' and thus tended to licence a broad definition of the perpetrators, 'impos[ing] collective guilt on Hutus.' (Waldorf, 2011, p. 49). In the dominant narrative of the genocide Tutsis are the primary victims, a few 'Hutu 
moderates' are acknowledged, and the RPF emerges untarnished, as the party that ended the atrocities (Pottier, 2002). In consequence, much less is known about the victims of Rwandese Patriotic Army (RPA) abuses during the 1990-94 civil war or of political violence since 1994; they have been largely excluded from justice and do not figure in the public memory (Lemarchand, 2009, p. 104). ${ }^{4}$

Since 1994, the RPF and some its political opponents have engaged in a competitive politics of victimhood, undermining relationships between Tutsi genocide survivors and victims of political violence and the recognition of what they have in common. The RPF account of the genocide has marginalised Hutus victims, while some political elites in exile have employed claims of Hutu victimhood to minimise the evidence of genocide (COSAR 2000; FDLR 2004). Both have discursively positioned Tutsi and Hutu victims - or victims of genocide, and victims of war and postgenocide abuses - in a symbolic opposition. This elite politics of victimhood compounds, and is also sustained by, actual divisions between victims of genocide, war and human rights abuses that were wrought in violence and reproduced in the mechanisms and practices of genocide justice. ${ }^{5}$ Even genocide survivors' associations are plagued by internal tensions and have faced pressure from the government, limiting their critical potential (Rombouts, 2004, pp 281-320). The genocide severed communities and destroyed social relations; it produced categorical differences, hardening ethnicities and limiting the potential for Rwandan victims to form a unified or inclusive group, or act collectively. Post-genocide politics has reinforced these divisions.

However, commonalities can be found in the testimonies of survivors and victims from a single locality despite the unique atrocity of the genocide and the heterogeneity in experiences of political violence. This chapter explores the power of testimonies to disturb politicized accounts of history and victimhood. Firstly, it brings together diverse testimony from genocide survivors and victims of political violence in the former prefecture of Cyangugu in south-west Rwanda, situating these in their historical context and showing how they enrich our understanding of the genocide and post-genocide period. This demonstrates that both victim testimony and ongoing human rights documentation are important resources to undermine accounts that minimise the experiences of genocide survivors by means of "moral equivalency, ${ }^{6}$ or marginalise the suffering of other victims of political violence.

Secondly, the chapter looks beyond the historical value of testimony to consider its political significance. Courts, human rights advocates and scholars have routinely employed survivor testimony as a source of information, woven into their own interpretations of events, yet it is also worth reflecting on their distinctive value as intrinsic critiques of political violence. My analysis foregrounds victim testimony as an act of agency and resistance to violence. Testimony contains complexities that are obscured in static and singular definitions of victimhood; it troubles neat categories, and reveals a tortuous and pervasive 'continuum of violence' (Richards, 2005). When abstracted from political framings, individual testimonies might contribute to the production of a 'critical memory' in the interests of peace and justice (Lemarchand, 2009, p.108).

\section{Approach}

Individual testimonies and life histories can help to answer the most difficult questions about the genocide in Rwanda. Micro-level studies that draw on local and personal accounts have uncovered some of the intricacies of local social relations and identities (Fujii, 2009; Hintjens, 2008); the specific influences and circumstances that shaped participation (Hatzfeld, 2005) and resistance (Palmer, 2014). They have also traced the varied threats and dilemmas that people endured in struggles for survival (Pottier, 2005). This approach encourages an appreciation of nuances and complexities that are obscured in political discourses (Pottier, 2005); it offers us precision and circumspection so we can 'see more inclusively... and recognize that a story can never be fully recovered' (Eisenstein, 2004: 43).

The methodological value of engaging with testimony is reinforced by an ethical rationale: after atrocities, there is a need to create spaces for victims to voice their own experiences (hooks, cited in McEvoy and Macconachie, p.498). Speaking for victims and 'imposing a coherent narrative' (Chakaravarti 2013, p.22) risks reinforcing their disempowerment. In consequence, the chapter begins with the presentation of a selection of testimonies from the archives of the human rights organisation, 
African Rights, ${ }^{7}$ situated in the context of one locality: the former préfecture of Cyangugu. Initially, this illustrates the value of testimony as a source for the writing of critical histories. But it also provides a basis upon which to further explore the political significance of testimony in the second part of the chapter. The discussion draws on interviews gathered during $\mathrm{PhD}$ field research in Rwanda (2006-7), while also relying on documentary sources and comparative studies of testimony, trauma and victimhood. My analysis is also substantially informed by close reading of thousands of victim and survivor testimonies while involved in human rights research $(1995-2003)^{8}$ and by the inspirational examples set by two Rwandan former colleagues, Pacifique Kabalisa and Félicien Bahizi, and the insights they have generously offered. ${ }^{9}$

\section{The history of genocide in Cyangugu}

In many ways, Cyangugu is an illustrative case that exemplifies patterns of violence elsewhere in Rwanda. It was one of twelve former préfectures during the period of $1994-2005^{10}$ and was home to Rwandans of different ethnicities. As elsewhere, this mixed population was caught up in and destroyed by the genocide. Tutsis were targeted in their homes and fled to churches and public buildings where many lost their lives in large-scale massacres. Tens of thousands were killed, local leaders organised attacks and many ordinary Rwandans participated in killings. Here as elsewhere, the genocide was 'authorized and obligatory' a form of 'law' (Straus, 2006 p.219; p.201). After the RPF victory in July, most of the Hutu residents fled into the neighbouring Congo (then Zaire) as refugees and some became victims of wars in Congo after 1996. The residents who survived, remained or returned were subject to the same set of national policies as other parts of the country. The postgenocide regime employed violence in its endeavour to extend control over the rural and urban population (Straus and Waldorf, 2011), and the people of Cyangugu were among those affected.

There are also some distinctive features of Cyangugu's history that are worthy of note. The place and its people have long been among the country's most neglected and marginalised. In part this is a consequence of a location that is geographically distant from the central state, behind a dense forest at the border with the Congo. This physical separation has shaped a popular perception of its people as somehow different: 'not real Rwandans'. ${ }^{11}$ It may also help to explain the strength of opposition politics here - Cyangugu was home to the leader of the largest opposition party before the genocide, the Mouvement Démocratique Républicain (MDR), Faustin Twagiramungu. ${ }^{12}$ Similarly, it relates to the unique aspects of Cyangugu's experience of the 1990-94 civil war and genocide period. The préfecture was the last region to come under RPF control and as such it escaped the effects of the civil war. It became the final outpost of the Interim Government before its members fled into exile in Zaire in July 1994. And from 23 June to 21 August 1994, it was also under the control of the French forces involved in Opération Turquoise. Lastly, a focus on Cyangugu is instructive because it occupies a special place in the historical record thanks to Catharine Newbury (1988) whose study of 'political oppression' in Kinyaga (the former Cyangugu) traced the political structures and processes that led to the Hutu revolution of 1959 back to the nineteenth century, exposing the deep roots of political violence in Rwanda.

\section{The roots of genocide: oppression and marginalisation}

Kinyaga (Cyangugu) was a 'frontier region', distant from the central state of the Kingdom of Rwanda until the reign of King Rwabugiri (1860-95) who established court there while launching military campaigns into the Congo. At that time, the population was heterogeneous and divided by clan and kinship identities. Later, people came to be increasingly defined by their relationships to the Rwandan court and by ethnic labels: 'Tuutsi and Hutu... came to assume a political importance, determining a person's life chances and relations with the authorities (Newbury, 1988, p.52). In this increasing social stratification, regional identities also mattered as new arrivals considered themselves superior to the locals, viewing all Kinyagans, including their fellow Tutsi, 'with scorn' (Newbury, 1988, p.50).

Since the nineteenth century, Kinyaga, with its strategic location and fertile hills, has been subject to repeated violent interventions, including successive invasions from external tyrants and colonial forces. In 1898, German authorities established a military post in the area, and it became the first 
region to experience colonial occupation. With the takeover and establishment of a Belgian administration after 1917, the region, once fragmented into chiefdoms and two small kingdoms, was centralised as a unified administrative unit. But when Kinyagan chiefs made a bid for local autonomy from the central court authorities, they were swiftly crushed, and the region saw increasing 'tightening of control from above' by the Belgian colonial state and its Rwandan Tutsi administrators. Kinyagans endured an array of colonial impositions and extractions (Newbury, 1988, p.132-47), while the territory was also exploited as a labour pool by European authorities across the border in Kivu, Congo.

The intense, abusive mode of indirect rule pursued by Tutsi chiefs, backed by the colonial state, shaped political consciousness in the region, as it did nationally. These were the grounds upon which the ethnic chauvinism of the 1959 Hutu revolution, and the ensuing post-independence order were built. As a result, despite the relatively large Tutsi population in parts of Kinyaga at independence, representatives of the new Hutu revolutionary parties swept to power in communal elections in 1960 (Newbury, 1988, p.200), presaging the establishment of a new political order privileging Hutu identity.

In the post-independence period, discrimination and violence against Tutsis was licenced nationally while regional inequalities were also entrenched, marginalising all the people of Cyangugu. The budget for the prefecture was proportionally half of that allocated to the three favoured regions of Gisenyi, Kigali and Ruhengeri from 1978-90, while the policy of 'ethnic and regional balancing' was unfair to Tutsis and Hutus from Cyangugu, reducing their access to secondary school places (Byanafashe and Rutayisire, 2011, pp 460-462). ${ }^{13}$ These disparities fuelled grievances and ethnic tensions at the local level.

In the same period, Cyangugu was affected by eruptions of political violence at moments of crisis for the post-independence Hutu-led regime. In 1963, there were attacks upon Tutsis in retaliation for 'Inyenzi' raids, launched by Tutsi political exiles forced out by the 1959 purges. In October 1993, when Burundian Hutu President Melchoir Ndadaye was killed by Tutsi officers, civilians in Cyangugu were again targeted, leading to an estimated 40 deaths (Des Forges, 1999, p.181). In February 1994, when Martin Bucyana, the CDR president was killed, Tutsi homes were burned.

\section{Accounts of genocide}

The killings in Cyangugu began on 7 April, the day after former President Habyarimana was assassinated (African Rights, 1995: 456-7). Within three months, the majority of Tutsis in Cyangugu were dead - estimates indicate that in total more than 100,000 people were killed (ICTR, 2004). ${ }^{14}$ Our knowledge of how individuals experienced the genocide in Cyangugu is largely based on various forms of testimony from survivors, witnesses and perpetrators, given in human rights reports, ICTR judgements, news reports and interviews. One of the earliest published sources is a human rights report from African Rights (1995) which quotes testimony taken from witnesses and survivors between February and April 1995 at length and verbatim. Human Rights Watch also discusses massacres in Shangi, Nyamasheke and Mibilizi (see Des Forges, 1999, p.301), and provides a detailed description of the torture and killing of a Hutu resident of Cyangugu who rejected the politics of the MRND-CDR and was 'killed by having parts of his body cut off, beginning with his extremities.' (des Forges, 1999, 308).

Existing reports have established beyond doubt that large-scale massacres occurred alongside individual targeting of Tutsis and Hutus. They revealed brutal killings, torture, rape, and looting. Similarly, ICTR judgements confirmed that tens of thousands of Tutsis were killed in large-scale massacres in Nyamasheke, Mibilizi, Shangi and Hanika parishes, Kamarampaka stadium, Gashirabwoba football field and Karambo military camp, among other killing sites. The 'Cyangugu trial' concluded beyond doubt that these massacres and other killings 'resulted in the deaths of massive numbers of mostly Tutsi victims' (ICTR, 2004, p.166).

Yet, compared to the scale of the atrocities, there is still much we do not know about how the genocide and its aftermath affected the people in Cyangugu. And existing publications are not critical 
histories, but mostly either advocacy reports calling for urgent investigations; or legal judgements determining the criminal responsibility of individuals. Moreover, these existing sources differ in various respects, including sometimes on the question of who was responsible. The International Criminal Tribunal for Rwanda (ICTR) brought charges against Yussuf Munyakazi, Siméon Nshamihigo, Samuel Imanishimwe, André Ntagerura and Emmanuel Bagambiki (the former préfet) on the basis of accusations that they had leading roles in the atrocities in Cyangugu. But while three of the accused were convicted on several counts, both Ntagerura and Bagambiki were acquitted, a judgement that led to protests and outrage in Cyangugu. None of the accusations of rape relevant to the 'Cyangugu trial' were included in the ICTR indictment. But Bagambiki was subsequently tried in Rwanda in absentia and convicted of rape as a form of genocide (HRW 2007).

Plural accounts of the genocide have emerged in public hearings in the gacaca courts ${ }^{15}$ held between 2002 and 2012 at community level, but these are as yet unpublished and their contribution to the historical record must be treated with caution. The trials led to thousands of new convictions and information about how some individuals died and where they were buried. But they also became a focus for threats, lies and manipulation. Some witnesses were killed, and especially in areas of Cyangugu where there were few survivors, there were others who felt 'too afraid to testify' (African Rights and Redress 2008, p. 9). Meanwhile the accused sought to use the confessions system to their advantage and to garner local support for their release, as one witness explained: 'they band together to contradict our testimony' (ibid, p. 42). The lessons of the rich literature on gacaca are bound to apply in in Cyangugu as elsewhere: the courts became an opportunity for 'corruption, score-settling, vengeance, the search for profit, and power plays' (Ingelaere 2016: 12); truth at gacaca was undermined by 'bandwagoning, balancing, and local power struggles' (Chakravarty 2016, p. 30).

Another source of information about the genocide has emerged through an independent investigation launched by the Government of Rwanda into the 'role of France in the 1994 genocide in Rwanda'. But here too we must be careful. The report raised a series of new allegations about the genocide in Cyangugu that had not surfaced in the early testimonies given to human rights or ICTR investigators, mostly from confessed perpetrators. The report accused French soldiers of Opération Turquoise of involvement in killing, rape and distribution of arms (Mucyo, 2008), and challenged previous accounts of how they saved lives at the Nyarushishi camp for displaced persons (Prunier, 1998, p. 292).

The various public accounts that exist of the genocide in Cyangugu all incorporate and rely upon survivor and victim testimony. They have also been shaped by instrumental political and legal goals, so that testimony is deployed as evidence in an argument, rather than recounted as a narrative for its own sake. In contrast, privately recounted, individual testimonies have intrinsic value, revealing precious personal truths about the events of the genocide and its aftermath in Cyangugu.

\section{Testimony from Cyangugu}

The following testimonies cover a span of over ten years from 1994-2005, and include both genocidal violence and of other forms of political violence. By placing them in a historical sequence, we can perceive the significance of the genocide as a cataclysm, while also observing a spectrum of violations since.

\section{Thaciana: Genocide in 1994}

Thaciana, a 43 -year old woman ${ }^{16}$ described her flight to a local parish on 7 April and her move from there to the stadium, 'forced' by the authorities. Her testimony describes the events of April-May 1994, including the selective abduction and killings of the refugees, and the heroism of two Hutu priests, Father Oscar Nkundayesu and Father Baudoin Busunyu, and a seminarian, Félicien Bahizi.

The interahamwe and soldiers paid regular visits to the [Kamarampaka] stadium to take people out to be shot. The prefect [Emmanuel Bagambiki] came in person, accompanied by the 
interahamwe, and read out a list of names of those wanted for questioning. These people were taken away and never seen again. They were killed outside the stadium... The génocidaires began by targeting intellectuals, businessmen and those who were well off. The simple peasants were left till last. We heard about how they died from people who had escaped, who came to the hospital and told us. In any case, a lot of them were shot. Those who were cut to pieces with machetes were usually those they had forced to dig their own graves so that they could throw them straight in afterwards.

Assessing that the situation [in the stadium] was deteriorating further, Father Oscar took the decision to start an escape route to the Congo. First, he found a Hutu, called Ntawumenyumunsi, who lived near Lake Kivu. He made an agreement with this man that he would take refugees across the lake in exchange for some reward. The Hutu did as he had promised without asking the refugees for anything. The second route [he] set up was with an ex-member of the interahamwe. This man was a well-known murderer who had killed so many Tutsis that he had decided that enough was enough and he didn't want to be involved in any more killings... He accepted the deal at a rate of 30.000 francs per person... The third and last escape route was from the parish of Nkanka and Father Busunyu played a very important part in it.

Three men: Father Oscar, Father Busunyu and Bahizi the trainee priest made extraordinary personal sacrifices to save our lives. They were all Hutus but they tried to save the lives of Tutsis. The survivors of Cyangugu will never forget that they owe their lives to these men. Father Busunyu's father was a very well-known member of the interahamwe... if he had known what he was doing he could have killed him with his own hands... sadly he died in a refugee camp in Congo. Father Oscar is still alive but his mother and sister were killed. ${ }^{17}$

\section{Clothilde: Genocide and rape in 1994}

Clothilde, a 53-year old woman, and her husband were both traders before the genocide. She described the loss of her entire family during the genocide. Her full testimony also spoke of her current situation, as a rape survivor living with HIV/AIDS.

I was a married mother of nine children, but they were all murdered, like their father, during the genocide. Right at the beginning of the genocide, we saw Hutus kill our Tutsi neighbours. As we were Tutsis, we sought refuge at the Catholic Parish of Nyamasheke... a huge attack was launched against the refugees in the church. During the chaos, a man I didn't know took me by the arm, led me into the priests' residence and raped me.

The massacres began on a Thursday and continued until Friday. It was always the same group of interahamwe who were responsible, with help from local residents who were our neighbours. The Thursday that I was raped, I came back to the church after the rapist left. I spent the night at the altar and left the church on the Saturday, leaving the corpses of my children, other members of my family, neighbours, friends and acquaintances behind me. All my children lost their lives in that church, while their father was killed in Cyesha. ${ }^{18}$

After I walked out of the parish, I headed for the home of a Hutu friend to ask him to hide me. I had a lot of injuries, caused by grenade splinters and blows from machetes. The family took care of me and cleaned my wounds every day. I lived there until the end of the genocide. ${ }^{19}$

\section{Jacqueline: Death after genocide in 1995}

Jacqueline, a young woman of 20, described her experiences during the genocide with her sister and brother-in-law, who was abducted and killed at the stadium in Kamembe. In her full testimony, she spoke of her their flight to Nyarushishi, where she said they 'received protection from the French.' After the genocide she and her sister returned to the family home and found all their family were dead and their home was destroyed. Soon afterwards, her sister died. 
From April 1994, until the country was taken over, we were really living in misery. Before the genocide, my older sister had a very nice life. At Kamembe stadium we had nothing to eat, we also didn't have any medicines. It was the same in Nyarushishi. When she fell sick her body couldn't fight the illness. After her death, I immediately wanted to commit suicide. She was the only one of my family who had escaped the genocide. I was the one who had to take care of the body. I had no money to buy the coffin; digging the grave was also difficult for me. The children were crying calling for their mother although she was dead. I had no-one to console me.

In the burial of my older sister, I was overcome with sorrow... After the burial, the children cried a lot asking me if their mother really left too. Instead of replying I used to cry. I had become the mother of these children, the children were crying and asking for food, when I didn't have anywhere to get it... The children asked me why they had all this suffering. I had nothing to reply to them, I also don't understand why the Hutus killed the Tutsis. I used to see other children of the same age who used to walk with their parents and friends, but I and my children have no-one to say hello to us, all the people who used to know my family were dead.

Jacqueline described her struggle to care for the children on her own and how one of them fell ill. By May 1995, he too was dead. ${ }^{20}$

\section{Fidèle: Killing of survivors in 1996}

A young man, Fidèle aged 20, explained that he and his Tutsi father were protected by friends during the genocide, while his Hutu mother 'was not a target'. After the genocide, they returned home to Bugarama commune, and Fidèle's father was appointed as local councillor. He spoke of the murder of his close friends, three genocide survivors who had lost their parents in the genocide and their Hutu domestic worker. Fidèle was at their home when they were visited by six men, armed with guns.

The men encircled us, constantly fired questions at us, asking where is the councillor? They asked for his name and... I lied and pretended I did not know who he was. They told Spéciose, Hyacinthe, Pierre and Pie (a Hutu who was their servant) to lie on the floor and some of the attackers kept an eye on them.

Fidèle was eventually released and immediately went to warn his parents. Together, they spent the night in the bush. But they heard gun shots and the following morning they found that their friends and their servant had been killed.

I believe that the four were killed because they were accusing génocidaires and demanding the return of their property. In a way, they were embarrassing witnesses... We really wonder when the killers will stop plaguing our lives and butchering our loved ones. ${ }^{21}$

\section{Anaclet: Attacks on Tutsis in Zaire in 1996}

Anaclet, aged 26, lost 18 members of his close family in the genocide, including his parents, his brother, three sisters and all their husbands and children. He survived by fleeing across the border to Bukavu, Zaire, across the Rusizi river. After the genocide, he remained in Bukavu working as a cook. He explained: 'I did not have the courage to return to Rwanda at the time because I knew very well that my family had been wiped out and I was well employed.' But the situation soon deteriorated.

The Rwandese refugees in the camps and elsewhere in Zaire began to stir up illfeeling. They verbally abused the Tutsis they met in Zaire and even wanted to kill them. Wherever we went we were threatened. In August 1996, the situation rapidly deteriorated and sparked off an armed confrontation between the FAR and the Banyamulenge rebels. The Zairean soldiers started disliking all the Tutsis, and the 
Hutu Rwandese refugees targeted us for elimination. We had to bribe them to avoid being targeted... The district leaders collaborated with the militiamen, the Zairean soldiers and the ex-FAR to capture the Tutsis. I had given $\$ 5$ to the leader of my district believing that he would leave me alone but I was mistaken. He arrested me himself and drove me to the roadblock in the district of Essence. I was kept at this roadblock all day and in the evening they began to beat me. I tried everything in my power to bribe them but in vain. I gave them packets of cigarettes that I had for selling and I gave them $\$ 50$. I was the only captured Rwandese Tutsi at the roadblock, all the others were Zairean Tutsis...

The soldiers got hold of me by the neck and took my remaining dollars which I had hidden in my shirt. They tied my hands behind my back and took me to the army prison... Throughout the journey to the detention centre, passers-by, men, women and children shouted insults and threw stones at me. They wanted to stone me to death. Before being thrown into the prison at Kije, I was badly tortured. The soldiers put nails in my left leg and beat me with a truncheon. The nails were small, about three or four centimetres long, but they were extremely painful.

When I arrived at the prison I thought that I had arrived in hell - the heat was unbearable and I was almost naked. In the cell, I met lots of Zairean Tutsis who had arrived before me. We were 36 in all and there were six corpses in the cell, three of them were Tutsis and the other three were Zairean Hutus from Bashi who had been arrested because they looked like Tutsis. The cell was incredibly unhygienic with corpses, urine and faeces. ${ }^{22}$

In October 1996, Banyamulenge rebels arrived in Bukavu and the prisoners managed to escape. Fidèle had survived and returned to Rwanda, but faced 'extreme poverty'.

\section{Révélien: Accused of 'genocide ideology' in 2004}

Révélien, aged 57, described his arrest on the charge of genocide ideology in 2004. He spoke about his suspicions about why he was targeted, including his 'family situation' which he described as relatively wealthy, as well as his role in local politics. Additionally, he spoke of pressures related to his role as a judge in gacaca and of the recent murder of his brother by RPF soldiers.

I am in prison charged with the crime of the ideology of genocide, an accusation that I reject in its entirety. I didn't know that I would be treated like this after everything I did to save the Tutsis of my cellule during the genocide. Also, I regret the influence I used to persuade the population to vote in favour of the RPF. I believed that I was in the process of electing a political force that would combat injustice, a true democracy. But, I [now] realize that most officials at the local level don't respect the orders of their superiors.

I am accused of insulting Kagame by saying that he adopted a policy of stealing the fields of Hutus for the benefit of his cows and that because of this, the farmers who live along the lakes will die of famine while Kagame's cows will grow fatter. I have never circulated such statements to the population... I am accused by a certain Mathias a survivor of the genocide. I am the one who helped him take refugee on the island of Idjwi... I know well that Mathias had sworn to make me suffer since I didn't support his son's candidacy for the post of councillor in our sector... he spread rumours saying that I had told people not to elect a Tutsi.

I appeared before the district tribunal about six months ago. However, no verdict has yet been given...

Another issue concerns the gacaca courts. I had been elected president of the gacaca jurisdiction in my sector. Since the beginning of audiences for gacaca in my region, I decided to give testimony about everything that I saw during the genocide. But there 
are people who accuse me of having taken part in the massacres of Tutsis... The accused do everything possible to escape justice. They bribe Mathias and our councillor, Alfred, also a survivor.

I can't end without telling you that a certain Phocas, a survivor, became allies with my aggressors to support them in the coup they mounted against me. He had collaborated with RPF soldiers in the murder of my younger brother, Pascal, a trader. They took 2,000,000 francs from him. His executioners were let out from jail; they were exonerated by the claim that my brother had raised money for the benefit of the FDLR. $^{23}$

\section{Daniel: Fear and threats in 2005}

Daniel, aged 36, is a Hutu who married his Tutsi wife three years before the genocide, against the wishes of both their families. He spoke of family pressures and local political tensions and observed an irony that the same influential Hutu businessmen who used to 'collaborate' with the Hutu exiles in 1996/7 are now the most 'ardent supporters of the RPF'. He gave an account of his experiences and analysis of the genocide, then spoke of his present fears following a 'false accusation' at a gacaca trial.

The genocide in our country met no obstacles because it was endorsed by the authorities who had the right to put an end to it. Senior military officers were, more than anyone else, the key drivers of the machine of extermination. Working closely with the leading interahamwe, they gave the example when it came to wiping out Tutsis. In Kamembe town, most of the first victims, educated people and businessmen, were shot by soldiers. Afterwards, and due to the encouragement of local officials, the population became involved in the genocide... acting out of fear.

Since officials at all levels were committed to the plan to exterminate the Tutsis, it was difficult, almost impossible, to save a few. Since you could be killed for hiding a Tutsi, most people preferred not to take the risk. I was obliged to try and save my brothersin-law and my sisters-in-law. I'm very happy that I did so, despite the huge costs it entailed for me.

But now I'm not at ease. Since they started to gather information for gacaca in the cellule where I lived during the genocide, I was surprised that one survivor accused me of trying to kill him. In order to give this crime more weight, he cited me in a group that included big businessmen who had distinguished themselves in the genocide. They are all living in exile.

Just as there were racist Hutus who spilled the blood of innocent people during the genocide, it is possible that there are survivors who use gacaca in a manner that is fundamentally racist. It's these people who consider all Hutus as génocidaires.

I'm not surprised if people now want to classify me as an interahamwe. In the last 11 years, my business has done very well. There are a lot of people who have it in for me and who would like to see me fail. The easiest route is to charge me with the crime of genocide. So, right now, I feel very precarious. ${ }^{24}$

\section{Revealing the complexities of genocide and political violence}

These testimonies from victims at different moments in Rwanda's violent history begin to expand our understanding of the genocide and post-genocide political violence. They expose the unique horror and devastation of the genocide, but also reflect its consequences and the persistent insecurity associated that has followed. They do not contain demands for revenge or retribution, instead they are preoccupied by questions of memory and justice. They also implicitly raise some questions about the details of other written records, including the ICTR judgement and the Mucyo report. ${ }^{25}$ 
The people described in the testimonies do not fit neatly into categories identified in national accounts of the genocide. Survivors describe being targeted as Tutsis, but they also detail other lives lost, including those of Hutus. Genocide perpetrators tend to be named specifically, as individuals, as well as in generalised terms. We find Hutus who saved lives, including in one case, a former genocide perpetrator. We also learn of the persecution of some Hutus, in one case a genocide survivor was accused of involvement. All these details are reminders that the labels of victim and perpetrator are situational; neither are necessarily static categories (McEvoy and McConnachie, 2012).

The testimonies also reveal the essence of atrocities in ways that reach beyond the facts of the events they describe. They express the trauma and incomprehension felt by survivors and victims and lack narrative coherence and interpretations that we find in other accounts of the genocide. All the accounts are spare and literal; they relate mainly events and observations, rather than attitudes and feelings; they include no embellishment. This is also in contrast with the general tenor of narrative discourse in Rwanda, that is often rich in proverbs, giving it an 'exquisite subtlety' and poetic quality (Newbury, 2011, p. xxxvi) as well as with official accounts of the genocide. The testimonies reflect a sense of shock and the difficulty of communicating or making meaning from atrocities and human rights abuses.

Even the small collection of testimonies cited above help to enrich our understanding of the history of the period in Cyangugu, although it remains a selective, unfinished account. Each testimony is confined to agonizing moments in the lives of certain individuals. The collection is not representative of the varieties of survivors and victims, nor does it catalogue all the types of political violence that have been inflicted on the people of Cyangugu. Each survivor and victim had more to tell about the histories of violence in the area and some of the most prominent events and individuals do not feature in the above accounts. Survivors and victims were not aware of events nearby, nor of course could they predict experiences of violence that were to follow in their own lives of the lives of others after the testimony was taken. ${ }^{26}$ This is an argument for the expansion of the archive of testimonies, to include people affected in different ways by the genocide or by other tragedies, as suggested by a genocide survivor from Nyamasheke, Cyangugu:

We need to try to make people think of a better future without massacres. As well as the victims of genocide there are also others who have problems: the refugees who came back from elsewhere. The consequences of the genocide are something which affects all the people of Rwanda. We need to think of all sides for all the Rwandese people, the genocide victims and perpetrators... People are left in misery. There are widows on all sides, and people whose husbands are in prison... All this society is sick, shocked, traumatised. So, the testimonies on the genocide should also be accompanied by testimonies from Congo victims. ${ }^{27}$

\section{Beyond victimhood: the ethics and politics of testimony}

Testifying to experiences of genocide and political violence entails a form of political agency. It may be the last resource that victims have left, and we know from reflections of Holocaust survivors that the process is simultaneously felt as painful and necessary. Survivors have described a 'desperate urge to testify' (Young, 1988, p.17) alongside a sense that it is impossible to communicate the depth of the atrocity; its 'enormity and noncredibility' (Levi, 2003 [1989], p.30). They have spoken of being 'possessed by the past' (La Capra, 2001: 89) and of an impression that it is ever present, 'etched in my memory' (2003 [1990], p.46). Their testimonies are borne out of an impulse to question and transform prevailing accounts of history. They involve a struggle to overcome the limits of language in order to bear witness (Young, 1988, p.16) and disclose the truth.

The revelations that emerge from such testimonies are in their essence condemnations of the violations and assertions of the dignity and humanity of those who suffered. As such they implicitly challenge the kind of politics that relies upon violence and war. The power of testimony is as a declaration of the trauma that was endured, almost regardless of its specificity about the violence; testimony consists in being true to the 'value' or meaning of facts, not simply their reality (Mesnard, 
2014, para. 15). Accounts given by victims express a profound truth: the 'social significance' (ibid) of violence as the 'breakage of a framework' (Laub, 1992, cited in LaCapra, 2001, p.88).

Certainly, testimony varies in its power to communicate the disturbing truth of the atrocities, just as victims differ and their situation changes. As events become historically distant, and politicallyauthorized narratives of traumatic events are constructed and disseminated, we might expect testimonies to lose their unmediated quality (Schudson, 1995, p.315) and to be gradually folded into the social dynamics of memory that tinge the past with traces of the present (Misztal, 2003).

Yet even after a period where memories may have faded or altered, the testimonies of people affected by atrocities and human rights abuses retain their importance for history and politics. Testimony enacts resistance to the original crime and calls for a recognition that the victims' lives mattered. It is truthful - voicing 'what the survivor believes is true' - and ethical: 'linked with an obligation to redress the injustice of political violence'. (Chakaravarti, 2013, p.24). By giving testimony, victims become survivors, displaying a form of agency and struggle; a determination to challenge the perpetrators. They voice their personal anguish: 'in the hope that something good may come' of it (Weine, 2006, p xiii).

\section{Conclusion}

The genocide was a 'moral shock'28 which severed social relations, but through their testimony, victims have contributed to exposing the truths of victimhood during and after the events and to the eventual possibility of political transformation. These individual experiences require us to acknowledge the magnitude and horror of the violations committed during the genocide, but they also locate this atrocity within a gendered continuum of violence stretching from before, during and after the genocide, affecting people of various ethnicities, and crossing borders. Some people have been repeatedly subject to various forms of violence under different regimes.

Observing the complex realities of violence up close, from a local perspective undermines the emphatic arguments of those who present monocausal explanations for participation such as ethnic hatreds or ethnic fears (Fujii, 2009). Instead we see that genocide is 'messy' and complicated (Fujii, 2009: 8) and its effects are enduring. Testimonies show that the period from April to July 1994 was a unique atrocity, but it was neither the beginning, nor the end of political violence. Rwandans have endured persistent political and structural violence over generations. By tracing life histories in one locality we can begin to understand the trajectory of violence, rife with local complexities. They also remind us of the political value of testimony as an attempt to expose and gain recognition for the truth, a courageous act that originates in an appeal for change, rather than a narrow attempt to attain static 'victimhood.'

Survivor and victim testimonies from Cyangugu implicitly or explicitly denounce violent politics. They identify the specific and plural ways in which people experienced the genocide and its aftermath and provide a corrective to narrow categorizations of victim and perpetrator groups. The collection and preservation of diverse testimonies is essential after atrocities. Not only is it essential for justice, but it is a means to counteract an exclusionary politics of victimhood and convey the complex realities of unconscionable suffering.

\section{Acknowledgments}

I am grateful to Pacifique Kabalisa and Félicien Bahizi for their many insights and for the privilege of working with them; their courage, integrity and commitment to humanity remains an inspiration. All errors are my own.

\section{References}

African Rights (1995) Rwanda: death, despair and defiance (Revised Edition), London: African Rights. 
African Rights and Redress (2008). Survivors and post-genocide justice in Rwanda: their experiences, perspectives and hopes: a summary. 10 December, Kigali and London.

Burnet, J. E. (2009). Whose genocide? whose truth? representations of victim and perpetrator in Rwanda. In A. Laban Hinton and K. Lewis O’Neill, Genocide truth, memory, and representation, Durham and London: Duke University Press.

Byanafashe, Déo \& Rutayisire Paul. (2011) en collaboration avec Joseph Jyoni Wa Karega, Charles Kabwete Mulinda, Célestin Kanimba Misago, Gamaliel Mbonimana Faustin Rutembesa, Histoire du Rwanda, des origins a la fin du XXe siècle. Commission Nationale pour L'Unité et la Reconciliation, Huye, Université Nationale du Rwanda.

Chakravarti, S. (2013). Agonism and Victim Testimony. In A Hirsch (Ed.). Theorising post-conflict reconciliation: agonism, restitution \& repair. New York: Routledge, pp.11-26.

Chakravarty, A. (2016). Investing in Authoritarian Rule: Punishment and Patronage in Rwanda's Gacaca Courts for Genocide Crimes, New York: Cambridge University Press.

COSAR, 2000, Actions du collectif du six avril 1994 Rwanda (COSAR). Bruxelles. 8 September. http://www.inshuti.org/cosar2.htm Accessed on 19 March 2009.

Davenport, C. \& Stam, A. C. (2009) What really happened in Rwanda? 6 October, http://faculty.virginia.edu/visc/Stam-VISC.pdf Accessed on 10 January 2017.

Des Forges, A. L., (1999) 'Leave none to tell the story': genocide in Rwanda (Vol. 3169, No. 189). Human Rights Watch, \& International Federation of Human Rights. New York: Human Rights Watch.

Eisenstein, Z. (2004) Against empire: feminisms, racism and 'the'. London: Zed Books.

FDLR (2004) 'Ten years later: it is time to pay a tribute in memoriam of all victims and let the truth on Rwandan tragedy come out' April, Press Release PP no 01/APR www.fdlr.org. Accessed on 19 March 2009.

Fujii, L. A. (2009) Killing neighbors: webs of violence in Rwanda. Ithaca, NY: Cornell University Press.

Hatzfeld, Jean (2005) A time for machetes, the Rwandan genocide: the killers speak, London: Serpent's Tail.

Hintjens H. (2008). Post-genocide identity politics in Rwanda. Ethnicities, Vol. 8, No. 1, pp 5-41.

Ibreck, R. (2010). The Politics of Mourning: Survivor Contributions to Memorials in Post-Genocide Rwanda. Memory Studies, 3:4, pp. 330-343.

ICTR (2004). Trial Chamber II, The Prosecutor v. André Ntagerura, Emmanuel Bagambiki, Samuel Imanishimwe, Case no. ICTR-99-46-T, http://unictr.unmict.org/sites/unictr.org/files/casedocuments/ictr-99-46/trial-judgements/en/040225.pdf Accessed on 22 July 2017.

Ingelaere, B. Inside Rwanda's Gacaca Courts: Seeking Justice after Genocide. Madison, Wisconsin: The University of Wisconsin Press.

LaCapra, D. (2001) Writing history, writing trauma, Baltimore and London: The John Hopkins Press.

Levi, P. (2003) [1989]. The drowned and the saved. In Levi, Neil and Rothberg, Michael, eds, 2003, The Holocaust: theoretical readings, Edinburgh: Edinburgh University Press pp 29-35.

MacKinnon, C. A. (2010). Engaged scholarship as method and vocation. Yale Journal of Law \& Feminism: Vol. 22: Issue. 2, Article 2. 193-205. 
Jambonews.net (2014). Brussels commemoration of all great lakes region tragedies victims. 1 May. http://www.jambonews.net/en/news/20140501-brussels-commemoration-of-all-great-lakes-regiontragedies-victims/ Accessed on 22 July 2017.

Lemarchand, R. (2009). The dynamics of violence in central Africa. Philadelphia: University of Pennsylvania Press.

Longman, T. (2011). Limitations to political reform: the undemocratic nature of transition in Rwanda. In Straus, S., \& Waldorf, L. (Eds.). Remaking Rwanda: state building and human rights after mass violence. Wisconsin: University of Wisconsin Press, pp. 25-47.

McEvoy, K., \& McConnachie, K. (2012). Victimology in transitional justice: victimhood, innocence and hierarchy. European Journal of Criminology, 9(5), 527-538.

Mesnard, P. (2014). Between testimony and memory, what place for Primo Levi? Il y a 70 ans, Auschwitz. Retour sur Primo Levi. Auschwitz Foundation International Quarterly, pp. 78-92.

Misztal, B. A. (2003). Theories of social remembering. Maidenhead: Open University Press.

Mucyo Report (2008) The role of France in the 1994 Rwandan genocide http://www.assatashakur.org/forum/breaking-down-understanding-our-enemies/35471-mucyo-reportrole-france-1994-rwandan-genocide.html Accessed on 12 January 2017.

Newbury, C. (1988). The cohesion of oppression: clientship and ethnicity in Rwanda, 1860-1960. New York: University of Columbia Press.

Newbury, D. (2011). The historian as human rights activist. In Straus, S., \& Waldorf, L. (Eds.). Remaking Rwanda: state building and human rights after mass violence. Wisconsin: University of Wisconsin Press, pp.25-4.

Palmer, N. (2014). Re-examining resistance in post-genocide Rwanda. Journal of Eastern African Studies, 8(2), pp. 231-245.

Peskin, V. (2005). Beyond victor's justice? the challenge of prosecuting the winners at the International Criminal Tribunals for the Former Yugoslavia and Rwanda. Journal of Human Rights, 4(2), pp. 213-231.

Pottier, J. (2002). Re-imagining Rwanda, Conflict, Survival and Disinformation in the Late Twentieth Century. Cambridge University Press: Cambridge.

Pottier, J. (2005). Escape from genocide: the politics of identity in Rwanda's massacres. In Vigdis Broch-Due (ed) Violence and belonging: the quest for identity in post-colonial Africa, London and New York: Routledge.

Prunier, G. (1998) The Rwanda crisis: history of a genocide, $2^{\text {nd }}$ revised edition, London, Hurst \& Co.

Prunier, G. (2009) Africa's world war, Congo, the Rwandan genocide, and the making of a continental catastrophe. Oxford: Oxford University Press.

Reyntjens, F. (2011). Waging (civil) war abroad: Rwanda and the DRC. In Straus, S., \& Waldorf, L. (Eds.). Remaking Rwanda: state building and human rights after mass violence. Wisconsin: University of Wisconsin Press, pp.25-47.

Reyntjens, F. (2015). Rwanda: progress or powder keg?. Journal of Democracy, 26(3), 19-33.

Richards P. (ed.) (2005) No peace, No war: an anthropology of contemporary armed conflicts, Oxford: James Currey.

Rombouts, H. (2004). Victim organisations and the politics of reparation: a case study on Rwanda. Antwerp: Intersentia.

Rurangwa, R. (2009). Genocide: my stolen Rwanda. Trans. Anna Brown, London: Reportage Press. 
RwaBaho (2015) Abbot Baudouin Busunyu, https://www.uclouvain.be/518847.html Accessed on 10 January 2017.

Schudson, M. (1995). Dynamics of distortion in collective memory. In Daniel Schacter (ed) Memory distortion, how minds, brains, and societies reconstruct the past. Cambridge: Harvard University Press.

Stearns, J. \& Borello, F. (2011). Bad karma: accountability for Rwandan crimes in the Congo. In Straus, S., \& Waldorf, L. (Eds.). Remaking Rwanda: state building and human rights after mass violence. Wisconsin: University of Wisconsin Press, pp.152-172.

Straus, S. (2006). The order of genocide, race, power and war in Rwanda. Ithaca and London: Cornell University Press.

Straus, S. \& Waldorf, L. (2011). Introduction: seeing like a post-conflict state. In Straus, S., \& Waldorf, L. (Eds.). Remaking Rwanda: state building and human rights after mass violence. Wisconsin: University of Wisconsin Press, pp. 3-22.

Waldorf. L. (2011). Instrumentalising genocide, the RPF's campaign against genocide ideology. In Straus, S., \& Waldorf, L. (eds) Remaking Rwanda: state building and human rights after mass violence. Wisconsin: University of Wisconsin Press. pp 48-66.

Young, James E. (1988) Writing and Rewriting the Holocaust, Narrative and the Consequences of Interpretation, Bloomington and Indianapolis: Indiana University Press.

\footnotetext{
${ }^{1}$ Claude Kanamugire, a Tutsi survivor from Ninzi, Cyangugu, cited in African Rights (1995, p.456).

${ }^{2}$ Félicien Bahizi, a Hutu who helped to protect Tutsis in Nyamasheke, Cyangugu, and was threatened during the genocide, cited in African Rights (1995, p. 457).

${ }^{3}$ The regime has favoured Tutsis in political appointments but it has also killed and threatened Tutsis, including genocide survivors (Reyntjens, 2015; see also Longman, 2011, pp. 28-32).

${ }^{4}$ The government has acknowledged that some individual soldiers are responsible for abuses (Waldorf, 2011, p.50) but refutes charges that these were authorised by the RPA (see Peskin, 2005). Additionally, it has sought to dismiss accusations of massacres during the war in the neighbouring Democratic Republic of Congo in 1997 (Reyntjens, 2011, pp 135-36).

${ }^{5}$ See Chakravarty's (2016) seminal study of gacaca courts.

${ }^{6}$ This apposite phrase is used by Waldorf (2011) firstly to refer to negationism by Hutu exiles promoting a claim that there was a double genocide, or an argument that the 1994 killings were a result of 'war and self-defence' (p.50); and secondly (p.81) to raise questions about the study of Davenport and Stam (2009).

${ }^{7}$ The testimonies were available to me in unedited versions and some of them have not been published previously. I worked at African Rights from 1996-2003. They form part of an archive includes over 300 testimonies related to the genocide in Cyangugu, and over 3000 testimonies in total (this estimate refers to original documents I have access to, not on the total numbers gathered by the organisation). African Rights publications have been cited as sources in numerous other works on the genocide (e.g. des Forges, 1999; Straus, 2006). I have used only first names for testimonies and initials for interviews for ethical reasons.

${ }^{8}$ This is a form of 'engaged scholarship' since as a human rights researcher the author was 'actively involved in the world of its subject matter' (MacKinnon 2010, p. 203).

${ }^{9}$ As human rights researchers from Cyangugu, Pacifique and Félicien have worked tirelessly to preserve the memory of genocide survivors and victims of human rights abuses, as well as honourable Rwandans who saved lives, including in their native prefecture. They were both targeted during the 1994 genocide. As a Tutsi, Pacifique was forced to flee Cyangugu in 1994, while Félicien, who is Hutu, faced threats because of its efforts to save lives in Cyangugu during the genocide. Both were
} 
also forced into exile due to threats after the genocide. Their insights have been invaluable in the research for this chapter during 2016-17, but all errors and omissions are my own.

${ }^{10}$ It was one of twelve préfectures during the period examined here. Local government administrative boundaries were redrawn in January 2006 as part of a decentralisation programme and Cyangugu was then included in Western province.

${ }^{11}$ PK and FB, personal communication, Brussels, November 2017.

${ }^{12}$ Twagiramungu became Prime Minister in the post-genocide Government of National Unity after the genocide, and was the sole opposing candidate against the incumbent President Paul Kagame in the 2003 elections. He has lived in exile since.

${ }^{13}$ My translation from the French.

${ }^{14}$ Straus (2006, p.55) estimates that the Tutsis population of Cyangugu was $9.6 \%$ of the overall number of Tutsis within Rwanda and that the percentage killed was 5.9\%. But he points out that the figures are unreliable due to problems with census and survey data. Relatedly, his calculations suggest that the number of Tutsi in the region was some 70,000. The ICTR estimates must include both Tutsis and any Hutus who died in the killings. The assertion that the majority of Tutsis were killed is beyond dispute and also confirmed by individual testimony eg. Note 1 .

${ }^{15}$ The gacaca courts were established to expedite genocide justice and to promote reconciliation through 'truth-telling'. They draw on community and custom but are driven by the state and contemporary concerns and are both punitive and restorative. Ultimately the courts heard close to 2 million cases and sentenced more than a million people on a range of crimes.

${ }^{16}$ The ages given refer to the age at the time the testimony was given.

${ }^{17}$ Testimony given in Cyangugu, 4 October 1999. Jacqueline's full testimony also lists the names of some of the dead, and those who were saved.

${ }^{18}$ The place where the sous-préfecture office was located.

${ }^{19}$ Testimony given in Cyangugu, August 2003.

${ }^{20}$ Testimony given in Cyangugu, May 1996.

${ }^{21}$ Testimony given in Cyangugu, March 1996.

${ }^{22}$ Testimony given in Cyangugu, November 1996.

${ }^{23}$ Testimony given in Cyangugu, June 2005. Révélien's full testimony also covered historical issues, including his arrest in 1986 on the grounds of 'having defended a Tutsi', and his role in saving lives during the genocide. The Forces démocratiques de libération du Rwanda (FDLR) is a militia group formed in 2000, largely composed Hutus based in the DRC and opposed to RPF rule in Rwanda and Tutsi influence in the region. Its leader Major General Sylvestre Mudacumura was deputy commander of the FAR Presidential Guard in Rwanda in 1994.

${ }^{24}$ Testimony given in Cyangugu, June 2005.

${ }^{25}$ For instance, Thaciana accuses former préfet Bagambiki directly, in contrast to the ICTR judgement of acquittal. Similarly, Jacqueline, who was at Nyarushishi, describes the French as protectors there, in contrast to the Mucyo report (2008).

${ }^{26}$ For instance, Father Busunyu, a priest who saved lives in Nyamasheke, named by Thaciana, was later killed in a massacre in the refugee camps in eastern DRC in 1997 (RwaBaho, 2015), while his compatriot Félicien Bahizi was persecuted by the RPF and forced into exile in 2009.

${ }^{27} \mathrm{JP}$, personal communication, Kigali, July 2006. This refers to Hutu refugees who were victims of massacres in the Congo war in 1996-7, (see Stearns and Borello, 2011). Also note victims and survivor groups have sometimes taken the lead in documenting violations and come together in associations and commemorations that explicitly include 'all that were victimized by genocide and wars' (Jambonews.net 2014).

${ }^{28}$ FB, personal communication, Kigali, July 2006. 